\title{
Remote Detection of Shoreline Changes in Eastern Bank of Laizhou Bay, North China
}

\author{
Yuandong Wang $\cdot$ Xiyong Hou $\cdot$ Mingming Jia $•$ \\ Ping Shi $\cdot$ Liangju Yu
}

Received: 16 September 2013 / Accepted: 12 January 2014 / Published online: 12 February 2014

(C) Indian Society of Remote Sensing 2014

\begin{abstract}
Sandy beaches of the eastern coast zone in Eastern Laizhou Bay represent the most popular tourist, recreational destinations and constitute some of the most valuable restates in China. This paper presents the detection of shoreline changes in Laizhou Bay East Bank using an automatic histogram thresholding algorithm on the basis of multi-temporal Landsat images. Shoreline change rates (SCR) and shoreline change areas (SCA) were retrieved using the statistical approach and zonal change detection method, respectively. Results showed that during 1979-2010 a large portion (over 59.8\%) of shoreline are dominated by a retreating process with an average rate of $-2.01 \mathrm{~m} /$ year, while other parts of shoreline exhibited a seaward advancing trend due to intense land reclamation activities. It is our anticipation that the result of this work would support sandy beaches protection and management in China coast.
\end{abstract}

Keywords Shoreline change $\cdot$ Coastal erosion $\cdot$ Automatic thresholding $\cdot$ Land reclamation

Subject classification codes $\cdot$ X87

Y. Wang $\cdot$ X. Hou $(\bowtie) \cdot$ P. Shi $\cdot$ L. Yu

Key Laboratory of Coastal Zone Environmental Processes, Yantai Institute of Coastal Zone Research, Chinese Academy of Sciences, 17 Chunhui RoadLaishan District Yantai 264003, People's Republic of China

e-mail: xyhou@yic.ac.cn

Y. Wang

Graduate University of Chinese Academy of Sciences,

Beijing 100049, People's Republic of China

M. Jia

Chinese Academy of Sciences, Northeast Institute of Geography and

Agroecology, Changchun 130012, People's Republic of China

\section{Introduction}

As one of the 27 features recognized by IGDC (International Geographic Data Committee), the shoreline is defined as the line of contact between land and a body of water ( $\mathrm{Li}$ et al. 2001). The location of shoreline and the changing position of this boundary through time are of elemental importance to coastal scientists, engineers, and managers (Douglas and Crowell 2000). Information about shoreline orientation, position and geometric shape is essential for navigation charting, marine boundary determination, and many coastal zone management activities. Shoreline change has been considered one of the most important dynamic processes in coastal area because population centers continue to shift toward this region and make it a more vulnerable area in developing countries. It has become important to map the shoreline change as an input data for coastal hazard assessment (Marfai et al. 2008). With no exception coastal beaches have been significantly affected by natural or anthropogenic activities.

Sandy ocean beaches of the eastern coast zone in China represent some of the most popular tourist, recreational destinations and constitute some of the most valuable restate in this country. These interfaces between water and land are the sites of intense residential and commercial development even though they are frequently subjected to various natural and human caused alterations including beach erosion and land reclamation. Coastal erosion is the permanent loss of land along the shoreline and is usually the result of a combination of both natural and human induced factors. Most important factors are winds and storms, near shore currents, relative sea level rise and slope processes. On the other hand, human induced factors of coastal changes include coastal engineering, land claim, construction of dams or reservoir, dredging, mining and water extraction. As a result of coastal activities, shoreline position can change over time. 
Acquisition of shoreline information is a fundamental work for addressing above coastal problems, measuring and characterizing land and water resources, such as the area of the land, and the movement of shoreline. However, it is a difficult, time consuming and sometimes impossible task for a large region when using traditional ground survey techniques (Cracknell 1999). As pointed by many coastal scientists (Morton 1991; Leatherman and Douglas 2003), tracking and investigating shoreline and coastal changes calls for rapid, highly accurate methods that minimize the mapping error and processing time and provide frequent and timely measurements. Remote sensing data proved to be a unique tool for coastal environment research. Maps derived from satellite data have a great potential to project recent changes of shorelines (Kevin and El Asmar 1999; Shaghude et al. 2003).

Remote sensing data has been utilized for the analysis of shoreline change in coastal and deltaic environment by many researchers. For example, Rebelo et al. (2009) used remote sensing and geographical information system (GIS) for wetland inventory, mapping and change analysis, Maiti and Bhattacharya (2009) analyzed shoreline change with a combination of remote sensing and statistical approach, Genz et al. (2007) researched beach variation on Hawaii, Wal et al. (2002) studied long-term morphological change in the Ribble Estuary, northwest England, Ghanavati et al. (2008) used Landsat TM and ETM+ data in order to monitor geomorphologic changes of Hendijan River Delta, southwestern Iran. Wu (2007) monitored coastline evolution of Nouakchott region (Mauritania) using the remote sensing approach, Vanderstraete et al. (2006) used multiple Landsat images to detect changes of the coastal zone near Hurghada in Egypt.

Remote sensing data has also been used in China as a powerful tool especially in coastal zone and city management activities. Jiang et al. (2003) performed an analysis of shoreline change along Bohai bay muddy coast on a time span of 130 years using remote sensing, Chang et al. (2004) monitored the dynamic shoreline change by remote sensing in the Yellow River Delta, Sun and Zhang (2004) conducted a survey in the coast area of Fujian province with an application of remote sensing techniques. Li and Michiel (2010) also carried out successful studies on shoreline change and urban expansion using remote sensing in the Pearl River delta and estuary.

In this study, the eastern bank of Laizhou bay as a part of Bohai bay located in Shandong Province was investigated in terms of shoreline changes. Sedimentation, deposition, erosion and human activities such as coastal agriculture, coastal engineering, land claim, dredging, mining and construction dams or reservoir have caused the morphological changes (shoreline advance or retreat) of shoreline along some parts of these important coastal beaches. Information about shoreline were first numerically extracted from muti-temporal Landsat data using image processing algorithms and then analyzed to retrieve shoreline change rates and shoreline change areas.

\section{Study Site}

The eastern bank of Laizhou bay is a stretch from Jimu Island in the border with Longkou city to Zhujiawang village with a length of $123 \mathrm{~km}$, including the drainage area of Longkou bay, the Sanshan island and Diaolong mouth (Fig. 1). This coast area is characterized by substantial mineral resources, popular tourist, dense population and intensive agricultural and industrial infrastructure. Since 1960s, the sandy shoreline along this region have long been suffering from coastal erosion problem due to severe anthropogenic activities such as mineral exploration, water extraction, and other types of resource harvesting, and the rivers and their subsidiaries (including Jie River, Zhuliu River, Zhuqiao River and Wang River) flowing though the district are highly affected by the human intervention/ engineering works upstream (dams, flow diversion). However, embankments have not yet been entirely erected along most parts of eastern bank of Laizhou bay. Hence, the dynamics of this representative sandy shoreline constitute a natural setting for studying the impacts of natural and anthropogenic upstream disturbances. Therefore, this study was focused on the beach shoreline changes of eastern Laizhou bay in order to support coastal engineering and management which would probably relieve coastal environment stresses and provide a case or reference for other homologous coastal areas from a perspective of scientific research.

\section{Data and Methods}

To detect shoreline changes in the beach of Eastern Laizhou Bay, four Landsat series images acquired in different dates were used in our work. Landsat Muti-spectral Scanner (MSS), Thematic Mapper (TM) and Enhanced Thematic Mapper $(\mathrm{ETM}+)$ data have been widely used in shoreline studies for many years because of their long record of global land-sea conditions with tens of meters spatial resolution. All images were rectified and projected using the Universal Transverse Mercator system in the world reference system (WGS84) datum with geographical error within 0.5 pixels. Further information about the specifications of satellite data in this work is listed in Table 1.

The methodology we used is to quantitatively detect multitemporal shorelines extracted from Landsat series images (Fig. 2). According to the literature, data records of different remote sensors are not directly comparable especially in quantitative remote sensing research because there are time differences in image acquisition, signal variations of exoatmospheric solar irradiance arising from spectral band 
Fig. 1 Location of the study area

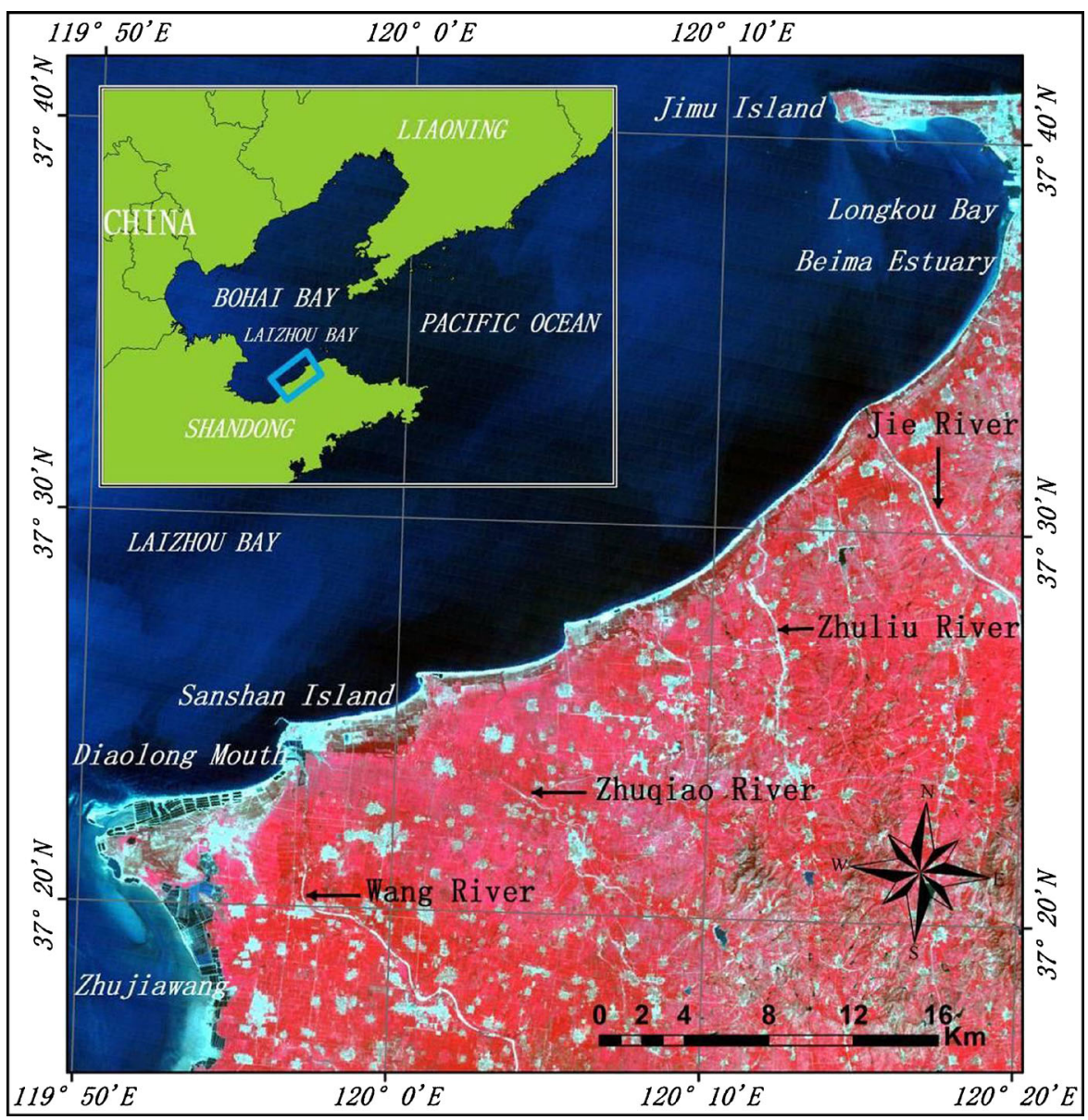

distinctions, and atmospheric effects of aerosol scattering under various weather conditions on image acquisition dates (Kuleli et al. 2011). Image pre-processing including radiometric calibration and atmospheric correction is necessary to get comparable data at the same level (Chander et al. 2009; Tyagi and Bhosle 2011. Therefore, digital numbers recorded by Landsat images were transformed to top of atmosphere reflectance according to Eq. 1 and then converted to ground surface reflectance using simple atmospheric correction of dark object subtraction according to Eq. 2:

$\operatorname{Rrs}_{T O A}=\pi L_{\lambda} d^{2} /\left(E_{\lambda} \cos \theta_{S}\right)$

$\operatorname{Rrs}_{G S R}=\operatorname{Rrs}_{T O A}-\alpha$

Where $R r s_{T O A}$ refers to planetary top of atmosphere reflectance, $\pi$ is mathematical constant equal to $\sim 3.14159 ; L_{\lambda}$ is spectral radiance at sensor's aperture ( $\left.\mathrm{W} \mathrm{m}^{-2} \mathrm{sr}^{-1} \mu \mathrm{m}^{-1}\right)$; $\mathrm{d}$ is Earth-Sun distance (astronomical units). $E_{\lambda}$ refers to mean exo-atmospheric solar irradiance $\left(\mathrm{W} \mathrm{m}^{-2} \mathrm{sr}^{-1} \mu \mathrm{m}^{-1}\right)$ and $\theta_{s}$ is solar zenith angle. $R r s_{G S R}$ refers to ground surface reflectance, $\alpha$ is the minimum reflectance value of near infrared band within deep water area.
In order to extract beach shorelines through land-water segmentation, we need to prepare index images of interested area with the maximum discrepancy in land and sea. The normalized differential water index (NDWI) has proved to be effective in increase the contrast between land and water feature by maximizing water reflectance in green and soil or vegetation feature in NIR (Sezgin and Sankur 2004). NDWI gray images were generated according to Eq. 3:

$N D W I=($ Green $-N I R) /($ Green $+N I R)$

Where Green is the green band such as MSS band 1 or TM/ ETM+ band 2, and NIR is the near infrared band such as MSS band 3 or TM/ETM+ band 4 . The generated NDWI images were shown in Fig. 2. These images were further enhanced through the enhanced Lee filtering in order to suppress possible speckle noises while preserving the edge information of image features (Lee 1981).

Next was to perform automatic shoreline extraction from enhanced NDWI images. So far many techniques have been developed to extract shorelines from remote sensing images. Manual, image enhancement, comparison of two independent land cover classifications, density slice using single or multiple bands multi-temporal or multi-spectral classification, both 


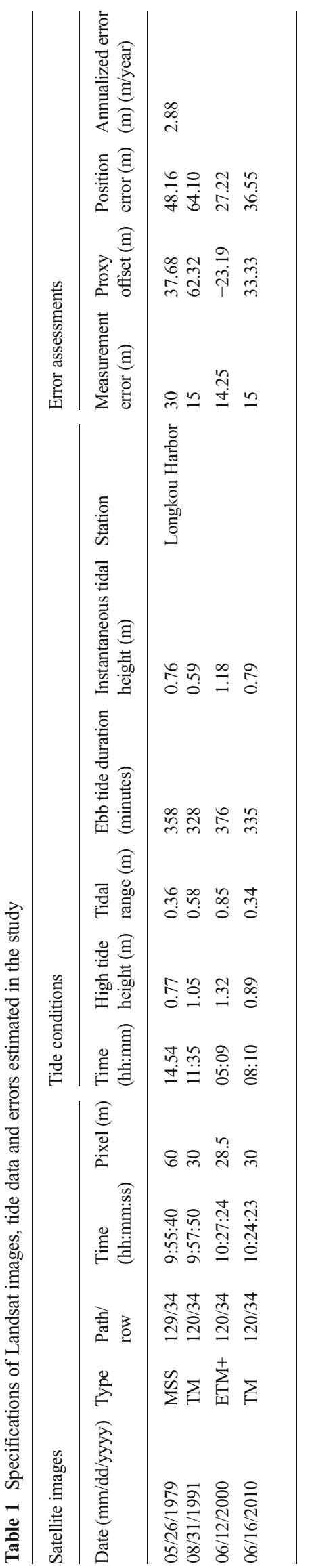

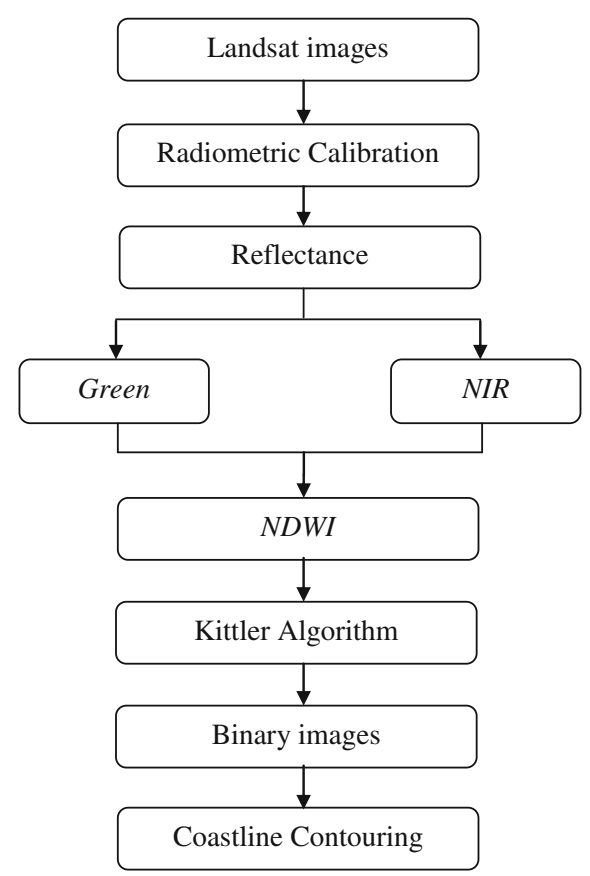

Fig. 2 Flow chart of shoreline extraction method used in this study

supervised and unsupervised (e.g. IDOSATA, PCA, Tasseled Cap) are most common techniques (Ryu et al. 2002). Besides, several image processing algorithms such as pre-segmentation, segmentation and post-segmentation have also been used (Liu and Jezek 2004; Kuleli et al. 2011). In this work, an automatic binarization method Kittler threshold algorithm was utilized on filtered NDWI gray images to delineate shoreline of coastal wetlands. The principle of this algorithm is to derive appropriate thresholds by the minimum error criterion through dynamic clustering (Kittler and Illingworth 1986). It is a robust and rapid algorithm dealing with images that have bimodal distribution histogram like NDWI images generated here (Figs. 2 and 3). As a result, NDWI images were separated into constituent homogeneous regions. The bordering pixels between segmented land and water regions of the produced binary images could be differentiated from other objects and traced into shoreline vector files for shoreline change analyzing.

Finally we calculated along shore shoreline change rate and shoreline change area for identified sections that behaved significant area variations (Figs. 4, 5, and 7). It is important to determine an appropriate method for detecting shoreline change rates of multiple historical shorelines because the characterization of shoreline changes have inherent uncertainties that depend upon offsets between different shoreline indicators or proxies, measurement errors from data sources that determine the accuracy of each shoreline position, sampling errors that account for the local variability of true shoreline positions in short term, and statistical errors associated with compiling and comparing shoreline positions (Maiti and Bhattacharya 2009; Yan et al. 2009). Linear regression has been found to be reliable for analysis of multiple shorelines. Rates of shoreline change were slopes of the least- 
Fig. 3 NDWI gray images and their bimodal distribution histograms
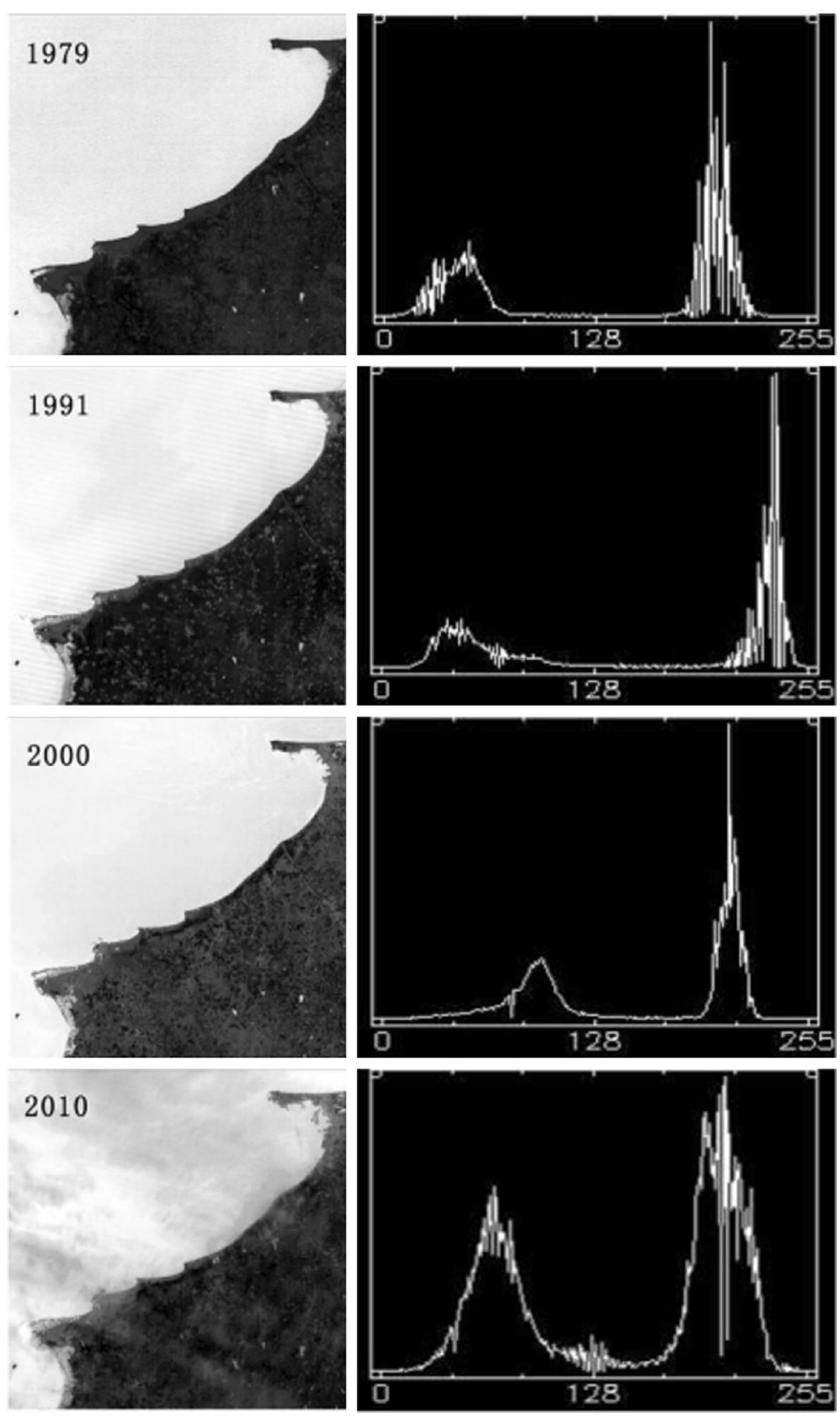

squares regression lines fitted to the intersection points of multiple shorelines and their corresponding transects casted perpendicular to them (Thieler et al. 2005; Genz et al. 2007; Maiti and Bhattacharya 2009; Kumar, et al. 2010; Kuleli et al. 2011; Wang et al. 2013). We utilized weighted linear regression (WLR) to determine alongshore multi-temporal shoreline change rates. WLR assumes heteroscedastic uncertainties and it means that the variance associated with each Y component (shoreline position) is usually not the same at each $\mathrm{X}$ component (different data acquisition time), if the variance $\left(E_{s p}{ }^{2}\right)$ or standard deviation $\left(E_{s p}\right)$ for each shoreline position is known, the weight $(w)$ is equal to $1 / E_{s p}{ }^{2}$ (Thieler et al. 2005; Genz et al. 2007). Greater emphasis is placed on data points which the position uncertainty is smaller.
Here $E_{s p}$ denotes the standard deviation for each shoreline position standing for total shoreline position uncertainty by taking the square of the sum of the squares of measurement error $\left(E_{m}\right)$ and shoreline proxy offset $\left(E_{p}\right)$. So total shoreline position uncertainty is written in the form of Eq. 4:

$E_{s p}=\sqrt{E_{m}^{2}+E_{p}^{2}}$

$E_{m}$ represents the maximum acceptable rectification error of Landsat images (Table 1). $E_{p}$ is the calculated maximum horizontal offset between instantaneous waterlines (IWL, image shorelines) and the mean high waterlines (MHWL, true 
Fig. 4 The generated transects along the eastern bank of Laizhou Bay, China

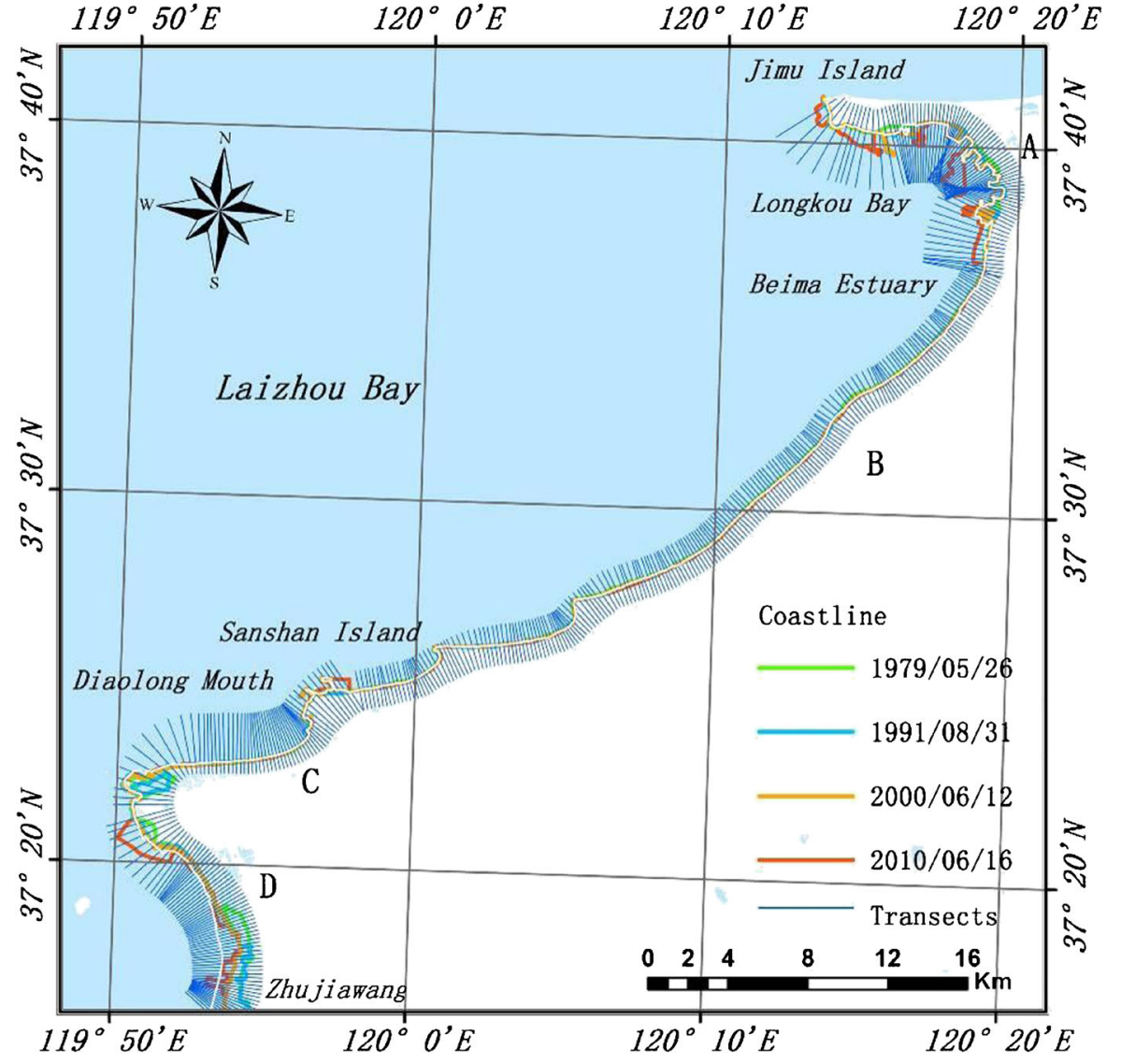

shorelines) in fields (clarified later). In this way a separate $E_{s p}$ can be calculated for each period, and these values can be annualized to provide an best error estimation $E_{a}$ for the shoreline change rates at a specific location (Table 1). The annualized error $\left(E_{a}\right)$ is calculated by Eq. 5 :

$E_{a}=\frac{\sqrt{\sum E_{s p i}^{2}}}{\text { time }}$

According to previous studies, tidal heights corresponding to instantaneous waterlines extracted from images can be calculated if the tidal station records of satellite over-passing dates are available, then local region slope can be deduced from the maximum and minimum instantaneous tidal heights we have calculated, at last the horizontal distances between MHWL and maximum IWL namely shoreline offsets can be obtained based on both their tidal heights and the deduced slope values (Mason et al. 1995; Mason et al. 1997; Ryu et al. 2002; Shen et al. 2008; Yan et al. 2009). We achieved the horizontal distances namely shoreline offsets $E_{p}$ between different waterlines (IWL and MHWL) using this 'waterline' method:

$E_{p}=\left(H-h_{\max }\right) / \tan \theta$
$H$ is the mean high tide record of nearby tidal station; $h_{\text {max }}$ and $\theta$ are the calculated local maximum value of instantaneous tidal heights and shoal slope according to Eqs. 7 and 8:

$h=H^{\prime}-R / 2 \times[1-\cos (t / T \times 180)]$

$\theta=\arctan \left[\left(h_{\max }-h_{\min }\right) / d\right]$

In Eq. 7, $H$ ' and $R$ refer to station records of high tide height and tidal range on each image acquisition date; $t$ is the time lag between high tide and image taking time on each date and $T$ refers to recorded ebb tidal duration. In Eq. $8, h_{\max }$ and $h_{\text {min }}$ are the calculated maximum and minimum value of tidal height of instantaneous waterlines, the distance between them is measured and denoted as $d$. The tide data listed in Table 1 for $E_{p}$ estimation were provided by China Oceanic Information Network affiliated to the State Oceanic Administration People's Republic of China.

In this study, proxy offsets accounting for tidal effects are the offsets between extracted image shorelines (instantaneous waterline, $I W L$ ) and local true shoreline (mean high waterline, $M H W L$ ), measurement errors are the maximum rectification errors of satellite images of each sensor type, sampling errors 

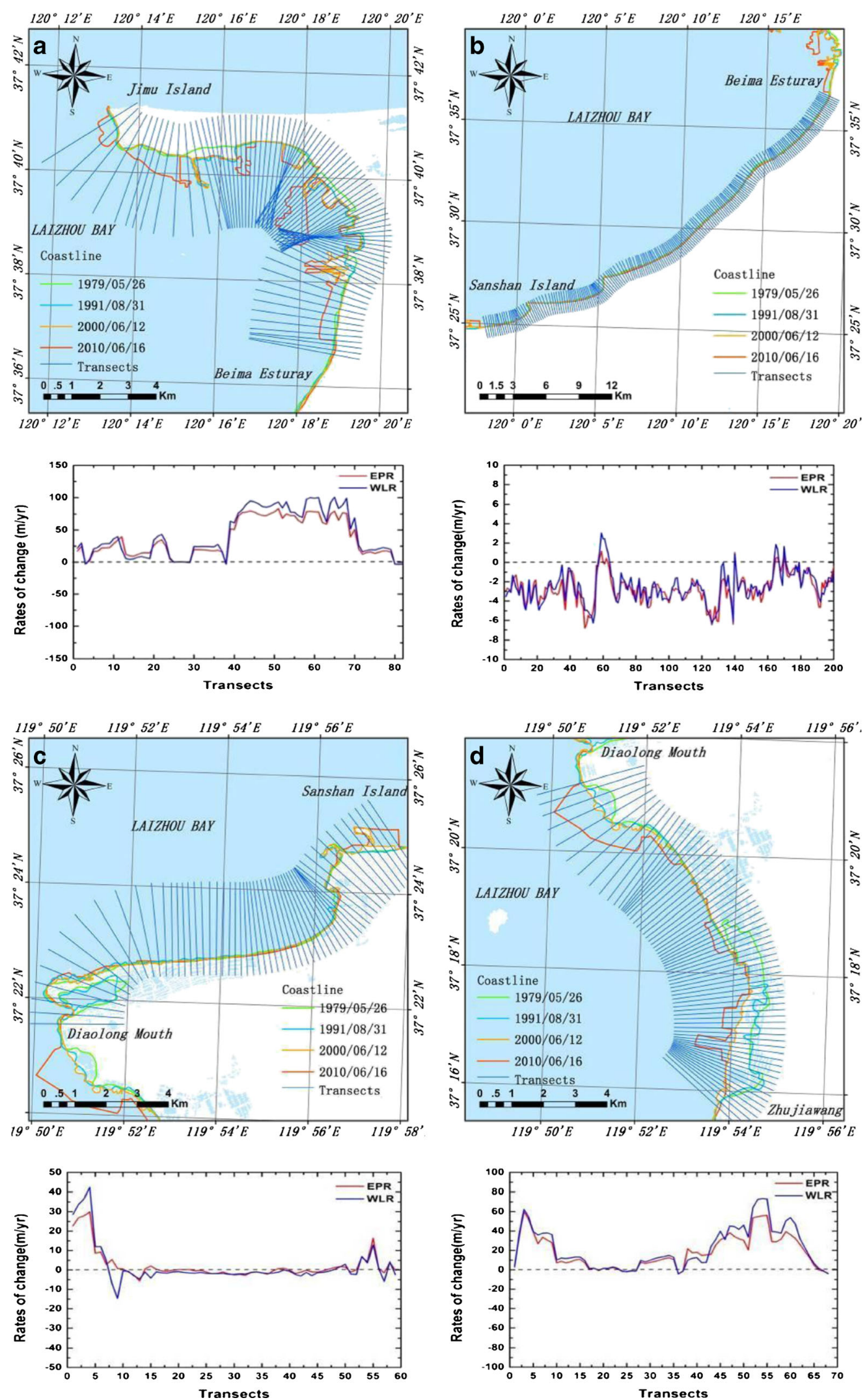

Fig. 5 Shoreline change rates (SCR) at each transect along four parts of shoreline

are not incorporated into uncertainty due to the limitation in collection of high frequency local data regarding short-term variability of true shoreline position at most coastal fields, statistical errors are the variability around the regression trend 
line, representing a $90 \%$ confidence interval for the slope of the regression line implying that with $90 \%$ statistical confidence the true rate of shoreline change falls within the range defined by the computed values plus or minus the error value. Statistical errors reflect both proxy offsets and measurement errors. Estimates of the maximum errors are provided in Tables 1 and 2 to show how each error contributes to uncertainty in the shoreline position and in the result of change rates. Results of shoreline change rates (retreat or advance) computed along four sections are shown in Figs. 4 and 5. For coastal sections that behaved significant area variations rather than merely alongshore perpendicular changes, their areas were determined by zonal change detection and the results were illustrated in Fig. 6.

\section{Results and Discussion}

Sandy beaches of the eastern bank of Laizhou Bay represent some of the most popular tourist and recreational destinations, and they also constitute some of the most valuable real estate in China. These ephemeral interfaces between water and land are the sites of intense residential and commercial development even though they are frequently subjected to natural hazards including flooding, storm impacts, and other coastal disturbances. Because population centers continue to shift toward the coast making the valuable coastal property much more vulnerable, an assessment of shoreline change was conducted in this research. Because shoreline position is one of the most commonly monitored indicators of environmental change, therefore using shoreline position as a proxy for coastal change is easily understood by those who are interested in historial movement of beaches (Morton 1996).

In this study, four periods of shoreline for 1979, 1991, 2000, 2010 were extracted from satellite remote sensing images using Kittler algorithm. Baselines were created landward with a buffering method in ArcGIS 9.3. Hundreds of transects were then casted along the shoreline at a space of $300 \mathrm{~m}$ with their orientation perpendicular to the baseline. At last, two statistical approaches EPR and WLR were both adopted to calculate the shoreline change rate based on the intersection points of each transect and shorelines. Results showed that the part 'B' (from Beima Estuary to Sanshan Island) of eastern bank of Laizhou bay experienced the highest retreat while part 'A' (from Jimu Island to Beima Estuary) had the greatest expansion. Summarized statistics of shoreline change rates is given in Table 2. The positive rate of shoreline change during this period represents coastal seaward advance and the negative indicates coastal landward retreat which possibly denotes erosion in beach region.

For the shoreline from Jimu Island to Beima Estury, it had an average landward retreat rate of $-2.15 \mathrm{~m} /$ year over 7 transects and an average seaward advance rate of $40.08 \mathrm{~m} /$ year over 75 transects (Fig. 5a). For the shoreline from Beima Estuary to Sanshan Island, the average retreat rate and advance rate were $-2.84 \mathrm{~m} /$ year and $0.55 \mathrm{~m} /$ year over 196 and 5 transects, respectively (Fig. 5b). Coastal retreat rate was found to be $-1.32 \mathrm{~m} /$ year along 32 transects for part ' $\mathrm{C}$ ', while the expansion rate was $6.55 \mathrm{~m} /$ year on 27 transects (Fig. 5c). The shoreline from Diaolong Mouth to Zhujiawang expanded at a rate of $-1.71 \mathrm{~m} /$ year on 10 transects and $22.10 \mathrm{~m} /$ year along 58 transects (Fig. 5 d).

Results of shoreline change present that shoreline changes including advance and retreat have caused significant morphological changes to the sandy beaches along eastern bank of Laizhou bay. Along the shoreline from Jimu Island to Beima Estuary, coastal expansion is found to be most significant at Longkou bay due to the construction of Longkou Harbor, with a maximum distance of $2,730 \mathrm{~m}$ advanced seaward at a maximum rate of $83.32 \mathrm{~m} /$ year (Fig. 5a). On the other hand, the shoreline between Beima Estuary and Sanshan Island is shown to be suffering from coastal retreat on $97.5 \%$ transects of this part with a maximum withdrawn distance of $300 \mathrm{~m}$ at a maximum rate of $-6.8 \mathrm{~m} /$ year (Fig. 5b). From Sanshan Island to Diaolong Mouth, the shoreline advances seaward most rapidly in Sanshan Island with a maximum distance of $870 \mathrm{~m}$ at a maximum rate of $29.99 \mathrm{~m} / \mathrm{year}$ due the construction of Laizhou Harbor while the other $54.2 \%$ transects remain retreat (Fig. 5c). For the part from Diaolong Mouth to Zhujiawang, the shoreline expands significantly to sea over $85.3 \%$ transects with a maximum distance of $1,510 \mathrm{~m}$ at a highest rate of 60.11 year $/ \mathrm{m}$ (Fig. 5d).

Overall, many part of shoreline within the study are dominated by a retreating process during 1979-2010 (Figs. 4 and

Table 2 Shoreline change trends of the eastern bank of Laizhou bay

\begin{tabular}{|c|c|c|c|c|c|c|c|c|c|}
\hline \multirow{2}{*}{$\begin{array}{l}\text { Part } \\
\text { A }\end{array}$} & \multicolumn{2}{|c|}{ Erosion trend $(\mathrm{m} /$ year $)(\%)$} & \multicolumn{2}{|c|}{ Accretion trend (m/year) $(\%)$} & \multirow{2}{*}{$\begin{array}{l}\begin{array}{l}\text { Mean } \\
\text { (m/year) }\end{array} \\
36.47\end{array}$} & \multirow{2}{*}{$\begin{array}{l}\text { Number of } \\
\text { transects }\end{array}$} & \multirow{2}{*}{$\begin{array}{l}\begin{array}{l}\text { Transect } \\
\text { length(m) }\end{array} \\
4000\end{array}$} & \multirow{2}{*}{$\begin{array}{l}\begin{array}{l}\text { Baseline } \\
\text { length }(\mathrm{km})\end{array} \\
24.6\end{array}$} & \multirow{2}{*}{$\begin{array}{l}\begin{array}{l}\text { Baseline distance } \\
\text { from shoreline }(\mathrm{m})\end{array} \\
1000\end{array}$} \\
\hline & -2.15 & 8.5 & 40.08 & 91.5 & & & & & \\
\hline B & -2.84 & 97.5 & 0.55 & 2.5 & -2.69 & 201 & 2000 & 60.3 & 1000 \\
\hline $\mathrm{C}$ & -1.32 & 54.2 & 6.55 & 45.8 & 2.28 & 59 & 3000 & 17.7 & 1000 \\
\hline $\mathrm{D}$ & -1.71 & 14.7 & 22.10 & 85.3 & 18.60 & 68 & 3000 & 20.4 & 1000 \\
\hline Total & -2.01 & 59.8 & 17.32 & 40.2 & 13.67 & - & _- & - & - \\
\hline
\end{tabular}


Fig. 6 Coastal erosion in the study field: the endangered houses on beach along the sea (left); the severely eroded banks (right)

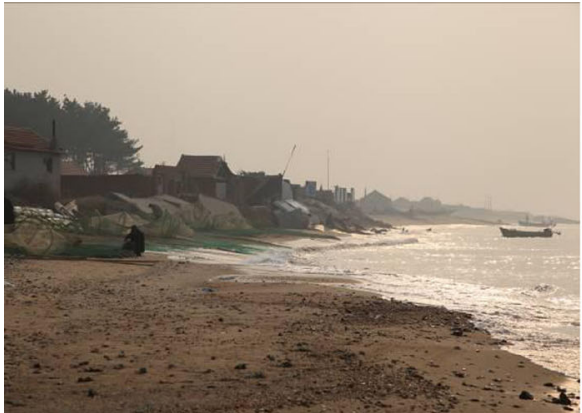

6). The average retreat trend is $-2.01 \mathrm{~m} /$ year over $59.8 \%$ transects (Table 2). The coastal retreat occurring here may be due to severe anthropogenic activities such as the construction of man-made structures along upstream rivers and dredging activities on riverbed. Over 100 dams have been constructed along Jie River, Zhuliu River, Zhuiao River Wang River (Fig. 1) and their subsidiaries. These dams could trap sediment and diminish the amount of sand supplied by watersheds to the littoral system (Du and Sun 2005). Long term sand dredging activities had deformed river channel and directly diminished runoff and the volume of sand that should be transported to the coastal area. In addition, local rise in relative sea level caused by subsidence because of underground resource exploration or extraction (mine, gold, gas, oil, water et al.) can also increase erosion stresses on sandy beaches (Fig. 6).
Previous studies of sea level along the China coast report that unusually high rates of relative sea level rise of more than $10 \mathrm{~mm} /$ year is common in deltas and coastal plains largely caused by over-pumping of ground water (Mei-e 1993).

To further reveal coastal shoreline changes of Eastern Laizhou Bay in the past 30 years, zonal change detection was also performed on the generated shoreline data (Fig. 7). It shows that from Jimu Island to Beima Estuary, coastal land gain was $4.34 \mathrm{~km}^{2}, 3.67 \mathrm{~km}^{2}$ in the first two phases and got a significantly increase in the last period exhibiting a great expansion trend. It is obvious that Longkou Harbon developments around this region have significantly increased land area. The part of shoreline between Beima Estuary and Sanshan Island suffered beach loss about $1.74 \mathrm{~km}^{2}$ during 1991-2000 and its intensity reached a maximum value of
Fig. 7 Zonal change detection of shoreline change areas (SCA)

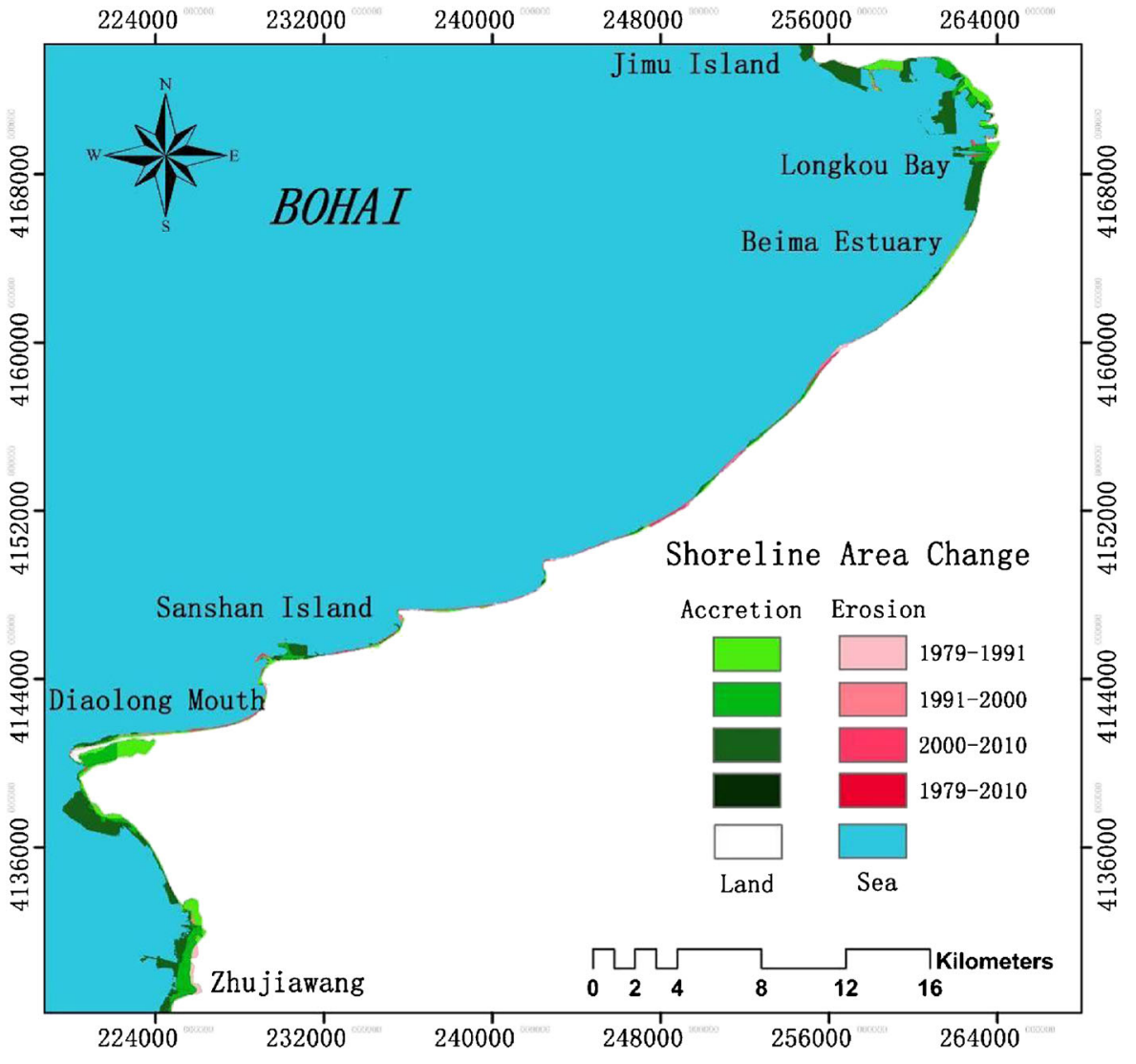


$1.52 \mathrm{~km}^{2}$ in $2000-2010$. Land gains were also found at the part from Sanshan Island to Diaolong Mouth in 1979-1991 $\left(0.69 \mathrm{~km}^{2}\right)$ and $2000-2010\left(0.7 \mathrm{~km}^{2}\right)$. The beach showed a better gain $\left(2.16 \mathrm{~km}^{2}\right.$ and $\left.3.47 \mathrm{~km}^{2}\right)$ from Diaolong Mouth to Zhujiawang exhibiting landward advancing trend. To be concise, the land gains were obvious at places where positive land reclamation were prevalent while natural sand beaches that lack of coastal engineering protections have been continually suffering land losses.

\section{Conclusion}

According to the findings of this research, to relieve the beach stresses caused by natural processes and human activities, management plans of coastal beaches should be considered to incorporate with regional or national management projects by decision makes in the future. Sandy beaches of eastern Laizhou Bay should be preserved to avoid unrecoverable changes leading by negative human impacts on their unique coastal environment. Public awareness of these important regions should be raised by authority to keep these valuable recreational areas from agricultural and industrial practices. New regulations and further studies are also needed to protect and regularly monitor the spatial and temporal changes of coastal beaches in our country.

Coastal beach shoreline movement is a complex phenomenon that is the result of both natural processes and man-made effects. Successfully managing the coastal beaches requires careful consideration of all the components of shoreline motion. Objectively, results of shoreline change detection using extracted images shorelines are only as reliable as: (1) measurement errors that determine the accuracy of extracted each shoreline position, (2) offsets between different shoreline indicators, (3) sampling errors that account for the variability of shoreline position, (4) statistical errors associated with compiling and comparing shoreline positions. In this study, although there were statistical uncertainties leading by data rectification and proxy offset caused by ocean tide effect, dominant trends of coastal beaches in eastern Laihou Bay during the past three decades were determined and revealed on the basis of multi-temporal historical shorelines extracted from Landsat images. While due to the insufficient availability of tidal data and access difficulty to specific site, detailed and accurately shoreline correction might be limited along designated coastal area, it is still practical to acquire important information about shoreline changes for coastal regions. Detailed field data accumulations are warranted in the long run.

The shoreline change analysis of this study may help future studies to reveal the local/global nature and causes of spatial variations in retreat and advance that have been reported in this paper. It is our anticipation that the results of this work would be applicable in management planning of the sandy beaches in eastern bank of Laizhou bay which is one of the most representative shoreline in China coast.

Acknowledgments This research is funded by the CAS Strategic Priority Research Program Grant No. XDA05130703 and the Knowledge Innovation of the Chinese Academy of Sciences No. KZCX2-YW-224. We would like to thank two anonymous reviewers and the associate editor for extremely helpful comments. We thank the China Oceanic Information Network and site data collection and processing staff for contributing to tidal station data, and the agencies and institutions that funded longterm records at these sites.

\section{References}

Chander, G., Markham, B. L., \& Helder, D. L. (2009). Summary of current radiometric calibration coefficients for Landsat MSS, TM, ETM+, and EO-1 ALI sensors. Remote Sensing of Environment, 113(2009), 893-903.

Chang, J., Liu, G. H., \& Liu, Q. S. (2004). Dynamic monitoring of coastline in the Yellow River Delta by remote sensing. GeoInformation Science, 6(1), 94-98.

Cracknell, A. P. (1999). Remote sensing techniques in estuaries and coastal zones an update. International Journal of Remote Sensing, 20(3), 485-496.

Douglas, B. C., \& Crowell, M. (2000). Long-term shoreline position prediction and error propagation. Journal of Coastal Research, 16(1), 145-152.

Du, G. Y., \& Sun, Z. Y. (2005). Research of artificial geologic disasters of coast belt in east bank of Laizhou Bay, Bohai Bay. Journal of Geological Hazards and Environment Preservation, 16(3), 225230.

Genz, A. S., Fletcher, C. H., Dunn, R. A., Frazer, L. N., \& Rooney, J. J. (2007). The predictive accuracy of shoreline change rate methods and along shore beach variation on Maui, Hawaii. Journal of Coastal Research, 23(1), 87-105.

Ghanavati, E., Firouzabadi, P. Z., Jangi, A. A., \& Khosravi, S. (2008). Monitoring geomorphologic changes using Landsat TM and ETMp data in the Hendijan River delta, southwest Iran. International Journal of Remote Sensing, 29(4), 945-959.

Jiang, Y., Li, L. F., Kang, H., \& Zhong, X. B. (2003). A remote sensing analysis of coastline change along the Bohai bay muddy coast in the past 130 years. Remote Sensing for Land \& Resources, 4(2003), 54 59.

Kevin, W., \& El Asmar, H. M. (1999). Monitoring changing position of coastlines using thematic mapper imagery, an example from the Nile Delta. Geomorphology, 29(1-2), 93-105.

Kittler, J., \& Illingworth, J. (1986). Minimum error thresholding. Pattern Recognition, 19(1), 41-47.

Kuleli, T., Guneroglu, A., Karsli, F., \& Dihkan, M. (2011). Automatic detection of shoreline change on coastal Ramsar wetlands of Turkey. Ocean Engineering, 38(10), 1141-1149.

Kumar, A., Narayana, A. C., \& Jayappa, K. S. (2010). Shoreline changes and morphology of spits along southern Karnataka, west coast of India: a remote sensing and statistics-based approach. Geomorphology, 120(3), 133-152.

Leatherman, S., \& Douglas, B. C. (2003). Seal level and coastal erosion require large-scale monitoring. EOS. Transactions of the American Geophysical Union, 84(2), 13-16.

Lee, J. S. (1981). Refined filtering of image noise using local statistics. Computer Graphics and Image Processing, 15(4), 380-389. 
Li, X. J., \& Michiel, C. J. (2010). Coastline change detection with satellite remote sensing for environmental management of the Pearl River Estuary, China. Journal of Marine Systems, 82(2010), S54-S61.

Li, R., Di, K., \& Ma, R. (2001). A comparative study of shoreline mapping techniques. Halifax: Proceedings of the Fourth International Symposium on Computer Mapping and GIS for Coastal Zone Management.

Liu, H., \& Jezek, K. C. (2004). Automated extraction of coastline from satellite imagery by integrating Canny edge detection and locally adaptive thresholding methods. International Journal of Remote Sensing, 25(5), 937-958.

Maiti, S., \& Bhattacharya, A. K. (2009). Shoreline change analysis and its application to prediction: a remote sensing and statistics based approach. Marine Geology, 257(1-4), 11-23.

Marfai, M. A., Almohammad, H., Dey, S., Susanto, B., \& King, L. (2008). Coastal dynamic and shoreline mapping: multi-sources spatial data analysis in Semarang Indonesia. Environmental Monitoring Assessment, 142(2-3), 297-308.

Mason, D. C., Davenport, I., \& Flather, R. A. (1995). Construction of an inter-tidal digital elevation model by the 'waterline' method. Geophysical Research Letters, 22(23), 3187-3190.

Mason, D. C., Davenport, I., \& Flather, R. A. (1997). Interpolation of an intertidal digital elevation model from heighted shorelines: a case study in the western wash. Estuarine Coastal and Shelf Science, 45(5), 599-612.

Mei-e, R. (1993). Relative sea-level changes in China over the last 80 years. Journal of Coastal Research, 9(1), 229-241.

Morton, R. (1991). Accurate shoreline mapping: Past, present, and future. New York: American Society of Civil Engineers.

Morton, R. A. (1996). Geoindicators of coastal wetlands and shorelines. In A. R. Berger \& W. J. Iams (Eds.), Geoindicators: Assessing rapid environmental changes in earth systems (pp. 207-230). Rotterdam: A.A. Balkema.

Rebelo, L. M., Finlayson, C. M., \& Nagabhatla, N. (2009). Remote sensing and GIS for wetland inventory, mapping and change analysis. Journal of Environmental Management, 90(7), 2144 2153.

Ryu, J., Won, J., Min, K.D. (2002). Waterline extraction from Landsat TM data in a tidal flat. A case study in Gomso bay, Korea. Technical
Report Series, vol. 83, Department of Geography and Anthropology Lousiana State University, pp. 442-456.

Sezgin, M., \& Sankur, B. (2004). Survey over image thresholding techniques and quantitative performance evaluation. Journal of Electronic Imaging, 13(1), 146-165.

Shaghude, Y. W., Wann" as, K. O., \& Lunde 'n, B. (2003). Assessment of shoreline changes in the western side of Zanzibar channel using satellite remote sensing. International Journal of Remote Sensing, 24(23), 4953-4967.

Shen, F., Hao, A., \& Wu, J. P. (2008). A remotely sensed approach on waterline extraction of silty tidal flat for DEM construction, a case study in Jiuduansha shoal of Yantze River. Acta Geodaetica Et Cartographica Sinica, 37(1), 102-107.

Sun, M. X., \& Zhang, W. (2004). Study on coastline remote sensing survey and application in Fujian Province. Journal of Oceanography in Taiwan Strait, 23(2), 213-219.

Thieler, E. R., Himmelstoss, E. A., Zichichi, J. L., \& Miller, T. L. (2005). Digital Shoreline Analysis System (DSAS) version 3.0: an ArcGIS extension for calculating shoreline change. US Geological Survey Open-File Report 2005-1304.

Tyagi, P., \& Bhosle, U. (2011). Atmospheric correction of remote sensed images in spatial and transform domain. International Journal of Image Processing, 5(5), 564-579.

Vanderstraete, T., Goossens, R., \& Ghabour, T. K. (2006). The use of multi-temporal Landsat images for the change detection of the coastal zone near Hurghada, Egypt. International Journal of Remote Sensing, 27(17), 3645-3655.

Wal, D., Pye, K., \& Neal, A. (2002). Long-term morphological change in the Ribble Estuary, northwest England. Marine Geology, 189(3-4), 249-266

Wang, Y. D., Hou, X. Y., Shi, P., \& Yu, L. J. (2013). Detecting shoreline changes in typical coastal wetlands of Bohai rim in North China. Wetlands, 33(4), 617-629.

Wu, W. (2007). Coastline evolution monitoring and estimation-a case study in the region of Nouakchott, Mauritania. International Journal of Remote Sensing, 28(24), 5461-5484.

Yan, H. B., Li, B. B., \& Chen, M. D. (2009). Progress of researches in coastline extraction based on RS technique. Areal Research and Development, 28(1), 101-105. 